\title{
Investigating Effecting Factors on Health Tourism in Iran and Providing Solutions for Its Development Using SWOT Model
}

\author{
Nasim Hosseinzadeh Nosrati ${ }^{1}$, Mohammadreza Hosseini ${ }^{2,}$, , Alireza Mousavi Jahan Abad ${ }^{3}$ \\ ${ }^{1}$ Management \& Accounting Department, Human Science Faculty, Seraj University, Tabriz, Iran \\ ${ }^{2}$ Management Department, Human Science Faculty, Central Branch, Islamic Azad University, Tehran, Iran \\ ${ }^{3}$ Management Department, Human Science Faculty, Payame Noor University, Varamin, Iran
}

\section{Email address:}

Nasim2hosseinzadeh@gmail.com (N. H. Nosrati), Mr.hosseini.fc@gmail.com (M. Hosseini),

Mousavi.alireza1989@gmail.com (A. M. J. Abad)

*Corresponding author

\section{To cite this article:}

Nasim Hosseinzadeh Nosrati, Mohammadreza Hosseini, Alireza Mousavi Jahan Abad. Investigating Effecting Factors on Health Tourism in Iran and Providing Solutions for Its Development Using SWOT Model. International Journal of Information and Communication Sciences. Vol. 5, No. 2, 2020, pp. 5-11. doi: 10.11648/j.ijics.20200502.11

Received: March 31, 2020; Accepted: April 16, 2020; Published: August 25, 2020

\begin{abstract}
Nowadays, the tourism an industry has its own complexities as the dynamic global and social phenomenon beyond as well as has become one of the largest and fastest growing industries. Health tourism is one of the areas of tourism that is more and more considered today. Health tourism is one of the most important forms of modern tourism. Therefore, effecting factors health tourism seems crucial and essential. Thus, in this paper, we have identified and ranked effecting factors on investment in health tourism. This research is applied in terms of purpose and descriptive-analytical in terms of method. The first population including health tourists visiting Iran for treatment during the year 2018 and the second population including health tourism specialists and experts and their numbers has been 350 and 43 , respectively. In this research,(Strength, Weakness, Opportunity, Threat) SWOT model and Friedman test have been used to identify, classify and analyze the strategic factors of internal and external environment and to obtain important factor of each internal and external matrices factors.
\end{abstract}

Keywords: Health Tourism, Solutions, SWOT Model, Iran

\section{Introduction}

Nowadays, the tourism an industry has its own complexities as the dynamic global and social phenomenon beyond as well as has become one of the largest and fastest growing industries. [8]. Tourism is an economic activity which because of its specific nature and characteristics provides proper opportunities for entrance to international trade arena regardless of countries' development level. [20]. This industry brings more social, economic, environmental and cultural benefits through the combination and simultaneous use of internal, external resources as well as increasing development of tourism has added more branches to this industry each of which directly and indirectly contributes to the gained income by tourism industry. [18]. On the other hand, rapid growth of tourist numbers around the world, urbanization, technology development and information volume increment has made proper utilization of modern technologies necessary for organizing tourism spaces. one of the main areas of tourism which is considered more and more today is health tourism. Health tourism is one of the considerable type of modern tourism. Since the 1990s, several factors have worked together to promote health tourism. On the other hand, high cost of medical services, long expectation time for patients as well as long needed time for insurance approval in developed countries has resulted that patients get their needed services from other countries. Health tourism is a relatively recent phenomenon that has developed in the last two decades. [16]. 
The health tourism trend was initially thought to be propelled by people seeking cheaper alternatives to cosmetic procedures; however, increasingly more vital health procedures (such as heart valve surgeries or knee transplants) are being offered and considered in destinations such as Thailand, Singapore, India, Taiwan [19], or Malaysia [13]. The concept of health tourism recently emerged in the international academic community to refer to travelling to other countries to seek medical treatment at a lower price or to avoid waiting lists in the country of origin [17]. On the other hand, health tourism has also had more growth in developing countries due to more monetization to historical and recreational tourism as well as globalization and trade liberalization in health services became the basis for rapid growth of this kind of tourism [6]. Southeast Asian countries such as Thailand, Malaysia and Singapore are the pioneers of health tourism. Southeast Asian countries such as Thailand, Malaysia and Singapore are health tourism pioneers. Also. India which is now global center of health tourism in addition to the extent offered services, tries hard to equip the infrastructures, to foster the technologies and therapeutic supplies, to keep costs down as well as to sing the therapeutic protocol. In order to, in the success rate of complicated operations such as hearth operations, bone marrow and kidney transplant is like the best hospitals in the world [13]. In the Middle East, Jordan and Turkey have been the pioneers in therapeutic tourism as well as in recent years, countries such as Bahrain and United Arab Emirates have also made efforts in this field. Iran also due to its advantages in this field such as special geographical situation, fruitful history of therapeutic science, facilities \& medical expert teams, low cost and high quality of therapeutic services as well as vast natural resources such as warm waters, spas and therapeutic sludge has decided to use of the existing advantages. Therefore, attention to health tourism is very important $\&$ crucial. Thus, in this paper, we have investigated effecting factors on health tourism and provide some solutions for its development using the SWOT model.

\subsection{Health Tourism}

The first recorded example of health tourism dates back to thousands years ago when Greek immigrants have traveled to a small land in the Saronic Gulf called Epiduria from all Mediterranean regions. It was the holy and healing place of Asclepius which has turned to starting destination of health tourism travel. Cities with spas and sanatoriums have also been considered as the first health tourism place. [9]. Health tourism which is called medical travel or hygienic tourism or global health care is a word which has been used at the first by travel agencies and mass media to describe growing trips across international borders for obtaining health cares. however, nowadays health tourism includes other concepts such as psychiatry, recovery care and even funeral services. Providers and consumers of these services usually communicate each other through informal communication channels. Of course, this type of communication means less discipline, lack of law supervision, uncertainty on quality, and less official references to possible reimbursement or compensation. [11]. [13], has defined therapeutic tourism as an organized travel outside the usual sphere of health care to improve health and regain it through medical intervention [13]. Ormond (2016) has defined medical tourism as providing effective medical services with tourism industry cooperation for patients who need surgery and other specialized services. This process facilitates by active institutions in medical Affairs and tourism. He has provided new technology gives the possibility of finding the best place for getting medical services. (Ormond, 2016).

\subsection{Health Tourism Challenges}

Understanding health tourism is not always positive. In some parts of the world, the extent of political issues can affect opinion and choice of health tourists to some extent they search anywhere else to get health \& therapeutic care. The biggest obstacle on health tourism path is persuading the possible viewers from long-distance. There can be important ethical issues on health tourism such as Illegal purchase of organs and tissues for organ transplants. Therefore, health tourism raised extent of ethical issues in countries with this kind of issues. Another issue is less attention to internal patients \& more attention to external patients. But, the main health tourism challenges have been provided below [14].

1. A variety of common infectious diseases existence in some of the countries such as India, Malaysia and so on.

2. The differences in types of hospitals and standards in various countries as well as quality of different postoperative care in various countries.

3. The existence of risks \& effects for patients with heart and respiratory diseases in traveling to distant destinations.

4. Effects of recreational and tourism after surgery activities.

5. Lack of suitable places for complaint on provided medical services.

\subsection{Health Tourism Destinations}

Basically based on Henderson's classification, high flow of health tourism in the patient sector is from high-cost countries to low-cost countries. There are more examples of developed countries customers which search for cheap treatments in developed countries. [5]. One of the effective factors in turning countries to Health Tourism destination is hospital accreditation. Hospital accreditation is selfevaluation \& external evaluation which has been defined for correct evaluation of the performance level in relation to the developed standards as well as implement methods for continuous improvement. Thus, it can be said that hospital with high accreditation rate are the most important destination of health tourism. The best countries have been cited blow; 
Table 1. Countries ranking in health tourism.

\begin{tabular}{llll}
\hline Country & ranking in health tourism & Country & ranking in health tourism \\
\hline Canada & 1 & Brazil & 22 \\
Great Britain & 2 & China & 23 \\
Israel & 3 & Poland & 24 \\
Singapore & 4 & Emirates & 25 \\
India & 5 & Malta & 26 \\
Germany & 6 & South Africa & 27 \\
France & 7 & Egypt & 28 \\
South Korea & 8 & Mexico & 29 \\
Italy & 9 & Qatar & 30 \\
Columbia & 10 & Morocco & 31 \\
Spain & 11 & Turkey & 32 \\
Japan & 12 & Jordan & 33 \\
Panama & 13 & Russia & 34 \\
Costa Rica & 14 & Oman & 35 \\
Dominican Republic & 15 & Tunisia & 36 \\
Dubai & 16 & Kuwait & 37 \\
Jamaica & 17 & Saudi Arabia & 38 \\
Thailand & 18 & Bahrain & 39 \\
Philippines & 19 & Lebanon & 40 \\
Taiwan & 20 & Iran & 41 \\
Argentina & 21 & & \\
\hline
\end{tabular}

\subsection{Effect of Health Tourism on Developing Countries}

In recent years, all of health tourism destination try to have an effective presence in health tourism competitive market through huge investments in public and private sectors. This have caused these destinations to introduce their services as travel packages to gain more income by attracting customers' attention. Some effects of health tourism on those countries are as follow;

1. Rapid development of essential infrastructure and health system to attract foreign patient

2. Increasing foreign exchange earnings from travel, accommodation and touring services

3. Development of educational facilities in medical and non-medical fields.

4. Control of brain drain \& return of native doctors working in other countries [7].

Favorable exchange rate changes in global economy have turned Asian countries to proper destinations for health tourism. Rapid upgrading and improvement of medical equipment used, trying to fill the gap caused by lack of equipment as well as providing services in accordance with world medical standards have improved service quality in these countries. Internet rise \& expansion as well as Information Technology progress have resulted in ease of access to the provided services in various destinations. [2]. Tourism phenomenon has caused to health tourism growth in countries are known as health tourism destination. Marketing and wide advertisement based on medical services in these countries have increased these destinations attractiveness beside tourism \& holidays. This market size in the world reached $\$ 40$ billion per year. [12].

\subsection{Health Tourism in Iran}

Iran is the seventeenth largest country in the world with a population of about 80 million is one of the oldest countries in the world. This country has the $10^{\text {th }}, 5^{\text {th }} \& 4^{\text {th }}$ rank in the world respectively in terms of natural tourism attractions, weather \& ancient civilization. The service segment has not been supported enough by the related organizations as well as this part of tourism market hasn't had good part of budget in spite of having $46 \%$ of GDP share. [10]. According to doctors, equipping specialized \& super specialized medical centers as well as providing suitable facilities for this sector help to this industry development. In Health tourism sector, not only tourism attraction is considered but also, Iran position in term of scientific, political, social and regional is reinforced. Yearly, about 35 million tourists around the world use mineral springs to cure various diseases but, Iran has small share from these tourists in comparison to other countries. While, health tourism has an important role in capital gain for the country. Many experts believe that Iran medicine history antiquity, unique medical centers to adjacent countries, low medical costs as well as potentials of tourism attractions provides a good context for investing in health tourism industry in Iran. [15].

\section{Research Background}

Ghanipour and Mohseni (2016) studied on a paper entitled the output of Health tourism in Iran.

This paper aims to evaluate the functions of health tourism in privatization, economic growth and production, positive valuation, employment creation, entrepreneurship, specialist human resource development and digital economy and so on. The results showed that all pillars of tourism have a positive relationship with the economy. Zareh and Faregh (2015) conducted a study to investigate the factors affecting the role of health tourism creation and its dynamics using the system dynamics approach. The simulation results show that the effect of these factors on the development of tourism will happen with a delay of 6 years, which is due because of to the introduction of Iran to foreign tourists. Also, it has also 
been shown by examining different scenarios that if any of these factors are ignored, it will delay the improvement of the tourism industry. Therefore, paying attention to all the factors can simultaneously make Iran flourish in the health tourism industry. Konu (2015) conducted a study on the development of a health tourism product with an ethnic approach. The results of this study showed that the ethnical approach leads to very diverse and extensive information gathering that can be used to develop new therapeutic tourism products. The researcher concluded that in order to succeed in the development of new health tourism products, the views of tourists must be carefully considered. Han, Choi and Ji (2015) used Importance-Performance Analysis (IPA) to develop programs to improve the tourism product. The results of this study showed that tourists' satisfaction with medical services is high, but their information and awareness about different medical centers in China is low. The results indicated that factors such as accurate tourism services, rapid response to tourist treatment requests, prompt service and cooperation with health tourism guides need to be improved in order to improve the health tourism product. Yom, Kim and Han (2015) evaluated the factors affecting the development of therapeutic tourism. The results of this survey showed that quality of health services, quality of tourism services, and satisfaction with medical services are the most important factors affecting Chinese tourists' loyalty to the health tourism product of Korea. The researchers said that using the results of this study could develop effective strategies to increase Chinese tourists' satisfaction and loyalty to the health tourism product. Han and Hyun (2015) examined the factors affecting customer retention in therapeutic tourism. The results of structural equation modeling showed that perceived quality, satisfaction and trust in medical center personnel had a significant effect on tourists' willingness to visit the destination country again. It was also found that tourists choose products that are reasonably priced.

\section{Research Methodology}

\subsection{Research Method}

This research is applied in terms of purpose and descriptive-analytical in terms of method. The present study has two distinct communities according to the research stages. The first community is health tourists who come to Iran for treatment during the year 2019 and the second is health tourism specialists and experts. The first population was 330 to collect information on health tourism status in Iran such as infrastructure, facilities, expectations and costs. A total of 310 questionnaires that could be reviewed were analyzed. The second sample includes 43 health tourism specialists and experts such as experts in health tourism agencies, experts in cultural heritage and tourism, international hospital managers, international insurance and tourism insurance managers and some professors. Academic and expert-related subjects were selected to respond to the expert and matrix questionnaires to identify strengths and weaknesses, threats and opportunities based on the analysis of data collected from the first sample, including 38 questionnaires. The community was collected and evaluated. SWOT model and Friedman test were used to identify, classify and analyze the strategic factors of internal and external environment and to obtain the coefficient of importance of each of the internal and external matrix factors.

\subsection{Research Objectives}

1) Investigating Factors Affecting Health Tourism in Iran

2) Identifying the Strengths, Weaknesses, Opportunities and Threats of Health Tourism Development in Iran

3) Providing Solutions for Health Tourism Development in Iran

\section{Research Findings}

At this stage, in order to determine the final SWOT matrix, namely, identifying the strengths and weaknesses, opportunities and threats of health tourism in Iran, first evaluate internal factors using IFE matrix, then evaluate external factors using EFE matrix, internal and external IEF analysis. Finally, macro strategies can be developed using the SFAS matrix.

\subsection{Internal Factors Evaluation Matrix}

This matrix is a tool for examining the internal factors of the organization. It actually assesses the strengths and weaknesses of the organizational units. It is mainly the opinions and judgments of managers and staff to provide an internal factors evaluation matrix.

Table 2. Internal Factors Matrix.

\begin{tabular}{|c|c|c|c|c|}
\hline \multicolumn{2}{|c|}{ Internal strategic factors } & \multirow[t]{2}{*}{ Significance factor } & \multirow[t]{2}{*}{ Rank } & \multirow[t]{2}{*}{ Final score } \\
\hline Stre & & & & \\
\hline $\mathrm{S} 1$ & $\begin{array}{l}\text { The ability to establish relationships with hospitals and private health centers in health } \\
\text { tourism }\end{array}$ & 0.058 & 4 & 0.23 \\
\hline S2 & $\begin{array}{l}\text { The Ability to establish partnerships with tourism companies and provide special services to } \\
\text { health tourists. }\end{array}$ & 0.053 & 4 & 0.21 \\
\hline S3 & $\begin{array}{l}\text { The Ability to use a broad network of health services throughout Iran to provide health } \\
\text { tourism services }\end{array}$ & 0.061 & 4 & 0.25 \\
\hline S4 & $\begin{array}{l}\text { The Ability to establish a relationship with Medical Sciences and Piraeus Medical Faculty in } \\
\text { order to train specialists }\end{array}$ & 0.036 & 3 & 0.11 \\
\hline S5 & The Ability of tourism centers to issue securities to attract funds & 0.038 & 4 & 0.15 \\
\hline S6 & The Ability to use hotels in health tourism & 0.036 & 4 & 0.14 \\
\hline
\end{tabular}




\begin{tabular}{|c|c|c|c|c|}
\hline \multicolumn{2}{|c|}{ Internal strategic factors } & \multirow{2}{*}{$\begin{array}{l}\text { Significance factor } \\
0.061\end{array}$} & \multirow{2}{*}{$\frac{\text { Rank }}{4}$} & \multirow{2}{*}{$\begin{array}{l}\text { Final score } \\
0.24\end{array}$} \\
\hline S7 & Having the required tourism and management knowledge & & & \\
\hline S8 & Ability to design and develop a variety of healthcare products and health tourism insurance & 0.062 & 4 & 0.25 \\
\hline S9 & Active presence in international finance to support modern social financial services & 0.055 & 4 & 0.22 \\
\hline $\mathrm{S} 10$ & The Existence of Up-to-date tourism and insurance knowledge in tourism centers & 0.058 & 4 & 0.23 \\
\hline S11 & Having strong information and communication systems and software in tourism centers & 0.042 & 4 & 0.17 \\
\hline $\mathrm{S} 12$ & Having professional human resources at the managers and experts levels & 0.052 & 4 & 0.21 \\
\hline $\mathrm{S} 13$ & Ability to finance through stock exchanges & 0.041 & 4 & 0.16 \\
\hline \multicolumn{4}{|c|}{ weaknesses } & 0.17 \\
\hline W1 & Non-Delegation in some of the hospital and hotel management issues & 0.04 & 1 & 0.04 \\
\hline W2 & The complexity of coordinating and integrating health tourism, bank, hospital \& hotel sectors. & 0.046 & 1 & 0.05 \\
\hline W3 & Currency exchange problems & 0.054 & 1 & 0.05 \\
\hline W4 & Lack of health tourism marketing research & 0.049 & 1 & 0.05 \\
\hline W5 & Inability to attract resources from international financial institutions & 0.035 & 2 & 0.07 \\
\hline W6 & Lack of Health Tourism existence in subsets of Tourism Holding Companies & 0.042 & 1 & $0 / 04$ \\
\hline W7 & Lack of health tourism specialist force & 0.039 & 2 & 0.08 \\
\hline Total & & 1 & & 3.12 \\
\hline
\end{tabular}

The sum of the total weights of internal factor scores 1 and their weighted score is 3.12.

\subsection{External Factor Evaluation Matrix}

External or environmental considerations include monitoring, evaluating, and disseminating information obtained about the organization's internal and external environments is among its key individuals effective (Hanger et al., 2008). The EFE External Factors Assessment Matrix is a tool for strategists to assess the political, economic, technological, socio-cultural, environmental, legal, and market factors at a given time.

The results of the evaluation of the legal categories related to the numerous opportunities and threats to health tourism activities under study in Iran are shown in the following matrices.

Table 3. External Factor Matrix.

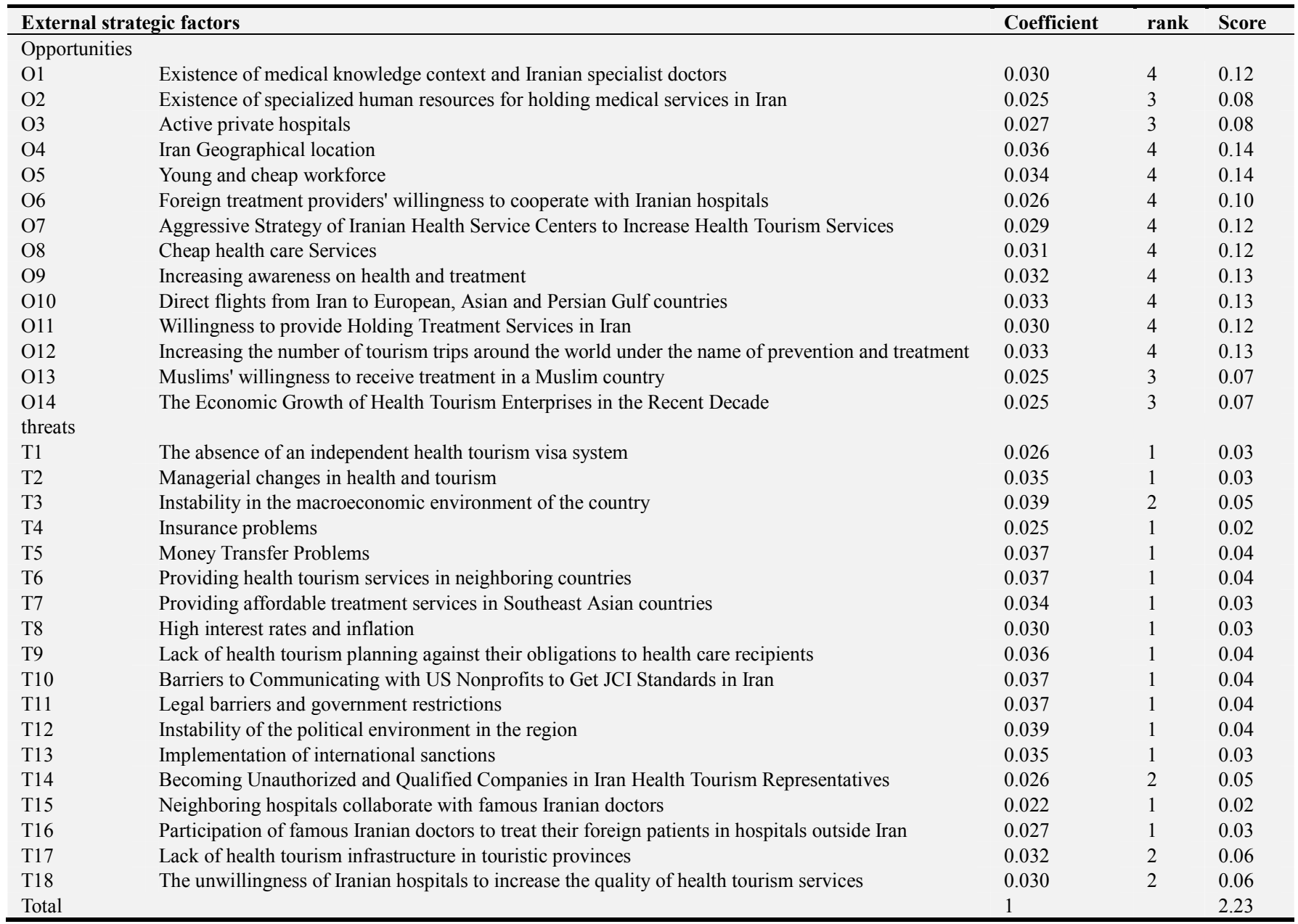

The sum of the total weights of the External Factors Score 1 and their Weighted Score is 2.23. 


\subsection{IEA External and Internal Factors Analysis}

In order to determine appropriate strategies in the tourism sector and to prepare the final SWOT matrix, each of the factors studied should be analyzed. For this purpose, column one (external and internal factors) lists the most important strengths, weaknesses, opportunities, and threats to the system. In the second column, the weight of each of these factors and their possible effect on the current strategic position of the system (based on findings from the analysis and analysis of the status quo) from one (most important) to zero (most unimportant) given. It shows the higher the weight, the greater the impact on the current and future position of the system. In the third column, given the key or normal strengths and weaknesses (opportunities and threats), rank 1 critical weakness, 2 normal weakness, 3 normal strengths, and 4 excellent strengths, respectively.

The weighted four-point column is obtained by multiplying the coefficient of importance by the rank of each agent and showing how a system responds to existing and potential agents and forces in its external environment.

The average weighted point of the whole system in a given field is always 2.5 (Arabi, 2012). The higher it is, the more important it is, and the lower it is, the less important it is. In terms of matrix scores, the strengths and weaknesses, opportunities, and threats are drawn below.

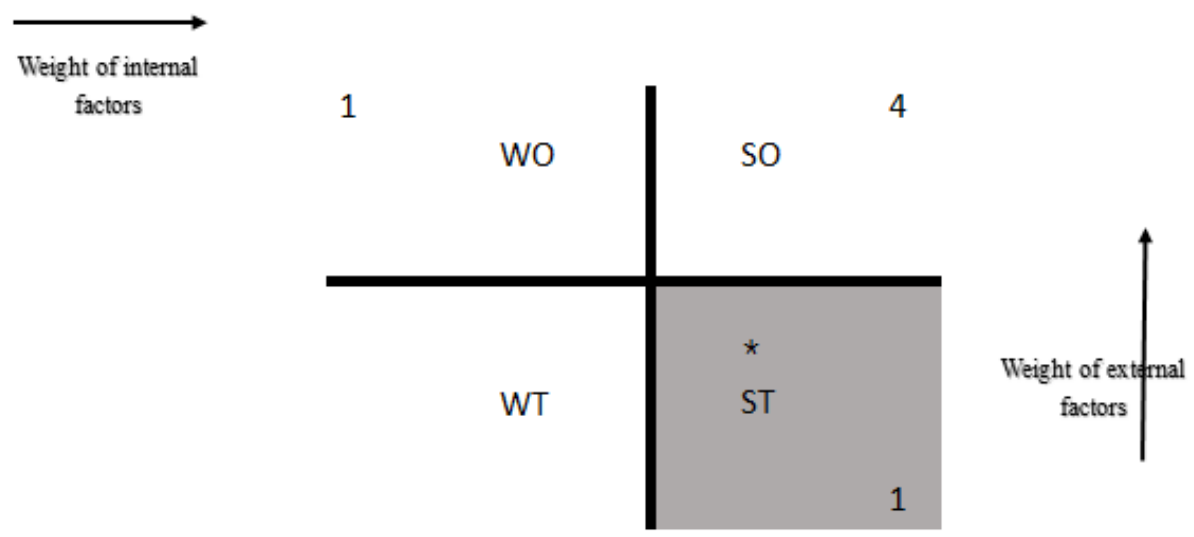

Figure 1. Prioritizing Health Tourism Strategies in Iran by IEA method.

Based on the results of the IEA analysis based on the importance of the set of internal and external factors influencing the health tourism development process, ST competitive strategies should be prioritized in the health tourism development plans of the area.

In competitive strategy, organizations are looking for sustainable competitive advantage. On the other hand, competitive strategy will be influenced by resources and capabilities of the organization and more resources of the organization will increase its capabilities and this situation will develop competitive strategies and thus it will gain competitive advantage for the organization.

\section{Conclusion}

The purpose of this study was to investigate the factors affecting health tourism in Iran and to present some strategies for its development using SWOT model. For this purpose, first, the characteristics of different study areas were extracted through a questionnaire and interview with health tourists and then evaluated by health tourism experts and experts. Strengths and weaknesses identified by the IFE matrix and opportunities and threats by the EFE matrix. After calculating the weighted score set for each of the factors mentioned in the above matrix, the proposed strategy was propounded. Then, the SFAS matrix describes their strategic factors and finally, the SWOT matrix describes strategies for health tourism development in different dimensions. The results of the IFE matrix analysis showed that the ability of tourism centers to collaborate in using a broad network of health services throughout Iran to provide health tourism services in all parts of Iran with respect to tourism destinations, the ability of tourism centers to establish hospital relationships, Private Health Centers and Tourism Centers Health, Tourism and management knowledge required, and Tourist and Insurance Knowledge in tourism centers are the most strengths and problems related to currency exchange and transfer using currency exchange, lack of Research Health tourism marketing, the complexity of harmonization Integration and management of health tourism sector, bank, hospital, hotel and lack of health tourism in the sub-holding subsidiaries tourism, including tourism, health tourism centers are the most important weaknesses. The results of the EFE matrix analysis of environmental factors indicate that Iran's geographical potentials (close to Europe and the Persian Gulf), young and cheap labor, increased tourism travel in the world as prevention and treatment, direct flights from Iran to European, Asian and Persian Gulf countries are the most important opportunities for health tourism development in Iran. Tourist centers and factors such as the instability of the political environment in the region, problems for transferring money, providing health tourism services in neighboring countries, lack of communication with US nonprofits to 
receive JCI standards in Iran, lack of health tourism planning for their obligations to health care recipients, and the existence of inexpensive treatment services in southeast Asians countries, are the major threats to health tourism activities in Iran. The main results of the study also show that Iran, due to its potential and actual potentials for health tourism and offering unique opportunities, is not far from the expected conditions of a health tourism hop in the region. High risk and appropriate market intrusion strategies, market development, market deepening, revisiting strategy, Health Tourism Services Development is recommended. It is suggested that these strategies emphasize internal weaknesses, taking advantage of external opportunities to address weaknesses.

\section{References}

[1] Al-Khaspour, Z., Ghomeyshi, M. \& Ghorbani Param, A., 2017. The Necessity of Establishing a Health Village in Iran to Promote Therapeutic Tourism. s. 1., International Conference on Architectural and Urban Engineering.

[2] Bhaidkar, A. \& Goswami, A., 2017. Medical tourism in India and the Health policy of the NDA government: An overview. Aweshkar Research Journal, 22 (1).

[3] Connell, J., 2013. Contemporary medical tourism: Conceptualisation, culture and commodification. Tourism Management, Volume 34, pp. 1-13.

[4] Firouzi, M. A. \& Zadvally Khajeh, S., 2018. SOAR Strategic Model a Step Towards Strategic Planning for Urban Tourism Development (Case Study: Tabriz Metropolitan Area). Regional Programing, 17 (25), p. 29-40.

[5] Fottler, M. D. et al., 2014. Can inbound and domestic medical tourism improve your bottom line? Identifying the potential of a US tourism market.. Journal of Healthcare Management, 59 (1), pp. 49-63.

[6] Garcia, B., 2006. Challenges and Opportunies in the Philippine Medical Tourism. SGV Review, p. 42-55.

[7] Golshiri Esfahani, Z., Rokne-din Eftekhari, A. \& Pour Taheri, M., 2016. Spatial Analysis of Health Tourism Security in Rural Areas of Iran. Geopolitical Quarterly, 11 (2), pp. 174197.

[8] Hezar Jirbee, J. \& Najafi, M. M., 2013. Sociological Study of Factors Affecting Tourism Development in Iran. Geography and Environmental Planning, 23 (47), pp. 133-150.

[9] Johnston, R. et al., 2015. Best care on home ground" versus "elitist healthcare": concerns and competing expectations for medical tourism development in Barbados. International journal for equity in health, 14 (1), p. 15.

[10] Keshavarzi, A., 2017. Health Tourism (therapeutic tourism). Razeh Nahan Publication.

[11] Lee, H. K. \& Fernando, Y., 2015. The antecedents and outcomes of the medical tourism supply chain. Tourism Management, Volume 46, pp. 148-157.

[12] Moghavvemi, S. et al., 2017. Connecting with prospective medical tourists online: A cross-sectional analysis of private hospital websites promoting medical tourism in India, Malaysia and Thailand. Tourism Management, Volume 58, pp. 154-163.

[13] Musa, G., Thirumoorthi, T. \& Doshi, D., 2012. Travel behaviour among inbound medical tourists in Kuala Lumpur. Current Issues in Tourism, 15 (6), pp. 525-543.

[14] Noree, T., Hanefeld, J. \& Smith, R., 2016. Medical tourism in Thailand: a cross-sectional study. Bulletin of the World Health Organization, 94 (1), pp. 30-36.

[15] Rashidi, M., Ramesht, M. H. \& Khoshhal Dastjerdie, J., 2014. Health Tourism in Iran. Ardabil Journal of Health (with Emphasis on Ranking the Therapeutic Properties of Selected Springs in Ardabil Province), 3 (1), pp. 49-57.

[16] Reisman, D., 2010. Health Tourism: social welfare through international trade. Cheltenham: Edward Elgar Publishing.

[17] Stojanović, M., Stojanović, D. \& Ranđelović, D., 2010. New trends in participation at tourist market under conditions of global economic crisis. Tourism \& Hospitality Management, pp. $1260-1268$.

[18] Tourani, S., Tabibi, S., Tofighi, S. \& ShaarbafchiZadeh, N., 2011. International Trade in Health Services in the Selected Countries of ASEAN Region; Challenges and Opportunities. Health Information Management, 7 (4).

[19] Ye, B., Qiu, H. \& Yuen, P., 2011. Motivations and experiences of Mainland Chinese medical tourists in Hong Kong. Tourism Management, 32 (5), pp. 1125-1127.

[20] Yu, J. Y. \& Ko, T. G., 2012. A cross-cultural study of perceptions of medical tourism among Chinese, Japanese and Korean tourists in Korea. Tourism Management, 33 (1), pp. $80-88$

[21] Zaeer Hejazie, L. \& Sepehrie Moghaddam, M., 2015. Investigating the Factors Affecting Tourism Development with Emphasis on Water Therapy and Tourism. s. 1., Third Scientific Conference on Modern Horizons in the Field of Civil Engineering, Architecture, Culture and Urban Management of Iran. 